\title{
MUTU BOKAR DARI KEBUN PETANI DI AREAL OPERASIONAL TAMBANG KABUPATEN MUSI BANYUASIN
}

\section{The Quality of Rubber Raw Material from Smallholder Plantations on Minning Operational Area at Musi Banyuasin District}

\author{
Afrizal Vachlepi, Iman Satra Nugraha dan Aprizal Alamsyah \\ Pusat Penelitian Karet - Balai Penelitian Sembawa \\ Jl. Raya Palembang Km. 29, Pangkalan Balai, Kotak Pos 1127, Palembang, 30001 \\ Sumatera Selatan, Indonesia \\ E-mail: a_vachlepi@yahoo.com
}

Diterima: 17 November 2015, Direvisi: 30 Juni 2016, Disetujui: 18 Juli 2016

\begin{abstract}
Abstrak
Bahan olah karet sebagian besar berasal dari perkebunan rakyat berupa slab dan lump. Persyaratan mutu tentang bahan olah karet tercantum dalam SNI 06-2047-2002. Evaluasi mutu bahan olah karet petani di sekitar areal operasional pertambangan belum banyak dilakukan. Tujuan penelitian ini adalah untuk mengetahui dan mengevaluasi mutu bokar petani karet di areal operasional tambang minyak dan gas di Kabupaten Musi Banyuasin, Sumatera Selatan berdasarkan SNI 06-2047-2002. Metode yang digunakan adalah metode survei terhadap 58 orang petani yang tersebar di 12 desa. Pemilihan desa untuk penelitian dilakukan secara purpossive sampling. Pengambilan sampel dilakukan dengan cara accidental sampling dan purpossive sampling. Parameter mutu bokar yang diambil terdiri atas kebersihan, ketebalan, jenis penggumpal, tempat pencetakan dan kondisi penyimpanan bokar. Data tersebut dibandingkan dengan persyaratan mutu slab pada SNI 06-2047-2002. Hasilnya, mutu bahan olah karet secara umum belum memenuhi standar baku yang dipersyaratkan SNI. Ketebalan slab tersebut $100 \%$ termasuk mutu IV. Penggunaan bahan penggumpal anjuran hanya $1,72 \%$. Seluruh slab yang dihasilkan petani $100 \%$ kotor. Tempat pencetakan slab yang digunakan beragam yaitu bak plastik, kotak kayu dan lubang tanah.
\end{abstract}

Kata kunci: karet, bahan olah, petani, mutu.

\section{Abstract}

Rubber raw materials were mostly made from smallholder plantations is lump and slab. The requirements of quality for rubber raw materials was listed on SNI 06-2047-2002. Quality evaluation of cultivator's rubber raw material at around the mining operation area hasn't been done. The objective of this research was determining and evaluating the quality of cultivator's rubber raw materials in the area of oil and gas mining operation in Musi Banyuasin District, South Sumatera based on SNI 06-2047-2002. The method used survey method to 58 cultivator that spread on 12 villages. Selection of the village to research was performed by purposive sampling. The sampling conducted by accidental and pusposive sampling. The parameters of rubber raw materials taken consists of cleanliness, thickness, coagulant type, mold, and storage conditions. The data compared with the slab quality requirements on SNI 06-2047-2002. The results is rubber raw material quality on general didn't comply with SNI standards required. The slab thickness were $100 \%$ including grade IV. The use of recommendation coagulant only $1.72 \%$. All slab produced by cultivator $100 \%$ dirty. Slab moulding container used variety such as plastic tubs, wood boxes and ground holes.

Keywords: rubber, raw material, cultivator, quality.

\section{PENDAHULUAN}

Karet merupakan komoditas ekspor penting bagi Indonesia karena menjadi penyumbang devisa negara kedua terbesar dari sektor non migas setelah kelapa sawit. Jumlah produksi karet alam Indonesia tahun 2012 mencapai 3,01 juta ton (Badan Pusat Statistik, 2013). Produksi karet alam tersebut sebagian besar berasal dari bahan olah karet (bokar) petani yang mempunyai luasan areal perkebunan karet sekitar $85 \%$ dari total perkebunan karet di Indonesia. Oleh karena itu kondisi bokar petani yang umumnya berupa slab dan lump sangat mempengaruhi mutu karet ekspor Indonesia.

Para konsumen karet Indonesia seringkali mengeluh karena mutu produk yang dihasilkan kurang seragam dan kurang konsisten. Keluhan tersebut berasal dari pihak pengimpor terutama pabrik ban sebagai konsumen utama. Karet remah Indonesia yang dikenal dengan Standard Indonesian Rubber (SIR) disinyalir mengandung 
kotoran dan kadar abu tinggi yang sangat berpengaruh terhadap mutu produk karet hilirnya (Syarifa dkk., 2013). Rendahnya mutu bokar tersebut dapat menurunkan daya saing karet alam Indonesia di pasar internasional.

Karet alam merupakan potensi sumber daya alam yang cukup besar di Sumatera Selatan (Setiawan, 2012). Peran sebagai provinsi penghasil karet alam terbesar di Indonesia dengan total produksi mencapai 1 juta ton per tahun atau 33\% total produksi Indonesia, menunjukkan bahwa petani karet di Sumatera Selatan memiliki peran yang penting dalam meningkatkan produksi dan menjaga mutu karet alam Indonesia.

Salah satu daerah penghasil karet alam terbesar di Sumatera Selatan yaitu Kabupaten Musi Banyuasin. Kabupaten ini, selain menghasilkan karet alam menjadi salah satu daerah penghasil minyak dan gas alam (migas) terbesar di Indonesia. Oleh karena itu, cukup banyak petani karet yang mengusahakan perkebunan karetnya di areal sekitar pertambangan migas. Lokasi petani dengan areal seperti tersebut umumnya berada jauh dari pusat informasi sehingga ada kemungkinan jika petani belum mengadopsi teknologi dan menerapkan pengolahan karet alam dengan baik dan benar. Bokar yang dihasilkan ada kemungkinan belum memenuhi persyaratan mutu sesuai standar SNI. Evaluasi mutu bokar yang dihasilkan petani terutama yang berasal dari sekitar areal pertambangan belum banyak dilakukan. Padahal, Areal di sekitar lokasi pertambangan saat ini mulai banyak dikembangkan sebagai lokasi perkebunan karet (Widyasari dan Rinojati, 2014). Tujuan penelitian ini adalah untuk mengetahui dan mengevaluasi mutu bokar yang dihasilkan petani karet yang berada di areal operasional tambang migas di Kabupaten Musi Banyuasin, Sumatera Selatan berdasarkan SNI 06-20472002 tentang bokar.

\section{TINJAUAN PUSTAKA}

Mutu karet ekspor Indonesia dipengaruhi oleh mutu bokar yang dihasilkan petani. Karet ekspor Indonesia sebagian besar diproduksi menggunakan bokar petani yang menjadi tulang punggung perkebunan karet Indonesia. Kondisi mutu bokar petani saat ini secara umum masih belum mengacu pada persyaratan teknis SNI Bokar.

Pemerintah Indonesia (Badan Standardisasi Nasional/BSN) menjaga mutu bokar yang berasal dari petani dengan mengeluarkan Standar Nasional Indonesia (SNI) 06-2047-2002 tentang bokar. Penerapan standar mutu sesuai SNI mutlak dilakukan untuk meningkatkan mutu karet Indonesia dan dapat dijadikan standar dalam proses transaksi jualbeli (pemasaran) bokar. Kegiatan sosialisasi dan implementasi standar mutu bokar sesuai SNI telah dilakukan pemerintah melalui kementerian dan dinas teknis terkait. Kementerian Pertanian sudah menerbitkan Peraturan Menteri Pertanian (Permentan) No. 38/Permentan/OT.140/8/2008 tentang Pedoman Pengolahan dan Pemasaran Bahan Olah Karet dalam rangka implementasi SNI tersebut (Kementerian Pertanian, 2008). Hal ini sejalan dengan implementasi SNI tersebut oleh Kementerian Perdagangan yang dituangkan dalam Peraturan Menteri Perdagangan (Permendag) No. 53/M-DAG/PER/10/2009 tentang Pengawasan Mutu Bahan Olah Komoditi Ekspor Standard Indonesian Rubber (Kementerian Perdagangan, 2009).

Peraturan tersebut mencantumkan persyaratan mengenai ukuran ketebalan dan kebersihan bokar serta jenis koagulan yang dapat digunakan dalam proses penggumpalan. Penggunaan koagulan anjuran menjadi sangat penting agar menghasilkan karet bermutu baik. Asam format dan asam asetat merupakan koagulan yang tidak merusak mutu karet (Triwojoso dalam Handayani, 2014). Petani terkendala dalam mendapatkan koagulan anjuran karena harganya yang relatif mahal dan ketersediaannya di tingkat petani seringkali tidak mudah ditemukan.

Petani karet di Sumatera Selatan sekitar 99\% menghasilkan bokar dalam bentuk slab dan lump. Berat bokar per keping berkisar 28-80 kg (Syarifa dkk., 2013). Jenis bokar yang beragam tersebut, khususnya dalam bentuk slab tebal dengan tingkat kontaminasi yang cukup tinggi, menjadi permasalahan yang mempengaruhi perkembangan teknologi industri barang jadi karet (Suwardin, 1991).

Upaya perbaikan mutu, penting pengolahan bokar yang sesuai dengan SNI. Pelaksanaannya memerlukan strategi meliputi aspek peningkatan produktivitas, penerapan pembakuan proses produksi, jaminan sarana dan peralatan, sistem pemasaran yang tepat, pembinaan dan penyuluhan, serta monitoring dan evaluasi kebijakan dan program pemerintah bekerjasama dengan Gapkindo (Suwardin \& Nancy, 1994).

Perkebunan rakyat (petani) tersebar di berbagai lokasi dan wilayah. Lokasi perkebunan ini sangat menentukan akses informasi yang diterima 
petani berkaitan dengan pengetahuan dan adopsi teknologi, baik budidaya maupun pengolahan karet alam. Hasil survei menunjukkan bahwa tingkat adopsi teknologi di perkebunan rakyat rendah (Syarifa dkk., 2012).

\section{METODE PENELITIAN}

Metode yang dilakukan pada penelitian ini adalah metode survei terhadap petani di 12 desa yang berada di sekitar areal operasional pertambangan migas di Kabupaten Musi Banyuasin, Sumatera Selatan. Pelaksanaan penelitian dilakukan pada bulan OktoberDesember 2014. Jumlah petani yang dijadikan sampel sekitar 58 orang yang tersebar di 12 desa tersebut. Pemilihan wilayah/desa untuk penelitian dilakukan secara purpossive sampling dengan kriteria desa berada di sekitar lokasi tambang. Pengambilan sampel dilakukan dengan cara accidental sampling dan purpossive sampling.
Parameter mutu bokar yang diambil pada survei tersebut terdiri atas kebersihan, ketebalan, jenis penggumpal, tempat penggumpalan dan kondisi penyimpanan bokar. Data parameter mutu yang dikumpul selanjutnya dibandingkan dengan persyaratan mutu slab seperti yang tercantum dalam SNI 06-2047-2002 (Tabel 1).

Parameter kebersihan yang diamati adalah ada tidaknya bahan-bahan lain bukan karet yang terdapat dalam slab petani. Bahanbahan lain bukan karet antara lain tatal, tanah, pasir, logam dan vulkanisat seperti yang tercantum dalam Peraturan Menteri Perdagangan (Permendag) No. 53 Tahun 2009 (Kementerian Perdagangan, 2009). Bahan penggumpal (koagulan) yang masuk dalam kategori tidak merusak mutu karet sesuai dengan rekomendasi Pusat Penelitian Karet berupa asap cair dan formula asap cair (Solichin dkk., 2012). Bahan lain yang digunakan sebagai penggumpal selain bahan tersebut tergolong dalam bahan penggumpal yang tidak direkomendasikan karena merusak mutu karet alam.

Tabel 1 SNI 06-2047-2002 tentang bahan olah karet.

\begin{tabular}{|c|c|c|c|c|c|}
\hline \multirow{2}{*}{ Jenis Uji/Parameter } & \multirow{2}{*}{ Satuan } & \multirow{2}{*}{$\begin{array}{l}\text { Lateks } \\
\text { Kebun } \\
\end{array}$} & \multicolumn{3}{|c|}{ Persyaratan } \\
\hline & & & Sit & Slab & Lump \\
\hline \multicolumn{6}{|l|}{$\begin{array}{l}\text { Kadar Karet Kering (min) } \\
\text { - Mutu I }\end{array}$} \\
\hline \multirow[t]{2}{*}{ - Mutu II } & $\%$ & 28 & - & - & - \\
\hline & $\%$ & 20 & - & - & - \\
\hline \multicolumn{6}{|l|}{$\begin{array}{l}\text { Ketebalan (T) } \\
\text { - Mutu I }\end{array}$} \\
\hline - Mutu II & $\mathrm{mm}$ & - & 3 & $<50$ & 50 \\
\hline - Mutu III & $\mathrm{mm}$ & - & 5 & $51-100$ & 100 \\
\hline - Mutu IV & $\mathrm{mm}$ & - & 10 & $101-150$ & 150 \\
\hline & $\mathrm{mm}$ & - & - & $>150$ & $>150$ \\
\hline Kebersihan (B) & - & - & $\begin{array}{l}\text { Tidak terdapat } \\
\text { kotoran }\end{array}$ & $\begin{array}{l}\text { Tidak terdapat } \\
\text { kotoran }\end{array}$ & $\begin{array}{ll}\text { Tidak } & \text { terdapat } \\
\text { kotoran } & \\
\end{array}$ \\
\hline Jenis Koagulan & - & - & $\begin{array}{lr}\text { Asam semut } \\
\text { dan bahan lain } \\
\text { yang tidak } \\
\text { merusak } \\
\text { karet }{ }^{*} \text { ) }\end{array}$ & $\begin{array}{lr}\text { Asam semut } \\
\text { dan bahan lain } \\
\text { yang tidak } \\
\text { merusak mutu } \\
\text { karet }{ }^{*} \text { ), serta } \\
\text { penggumpalan } \\
\text { alami }\end{array}$ & $\begin{array}{l}\text { Asam semut dan } \\
\text { bahan lain yang } \\
\text { tidak merusak } \\
\text { mutu karet }{ }^{*} \text { ), serta } \\
\text { penggumpalan } \\
\text { alami }\end{array}$ \\
\hline
\end{tabular}

Sumber: Badan Standardisasi Nasional (2002).

\section{HASIL DAN PEMBAHASAN}

\subsection{Ketebalan Bokar}

Hasil survei dan evaluasi terhadap sekitar 58 orang petani karet di areal operasional tambang migas diketahui bahwa 100\% bokar yang dihasilkan berupa slab yang mempunyai ketebalan lebih dari $150 \mathrm{~mm}$ atau $15 \mathrm{~cm}$. Berdasarkan analisis mutu sesuai dengan persyaratan SNI bokar (Tabel 1), seluruh slab yang dihasilkan hanya masuk ke dalam kategori mutu IV (Gambar 1). Tingginya ketebalan bokar yang dihasilkan disebabkan petani karet di daerah tersebut membuat slab menggunakan koagulum berupa lump mangkok (Gambar 2). Koagulum lump mangkok mempunyai ketebalan lebih dari $10 \mathrm{~cm}$. Hal ini mengakibatkan pada saat pencetakan lump mangkok menjadi slab dengan penambahan lateks, bokar yang dihasilkan petani menjadi lebih tebal. 


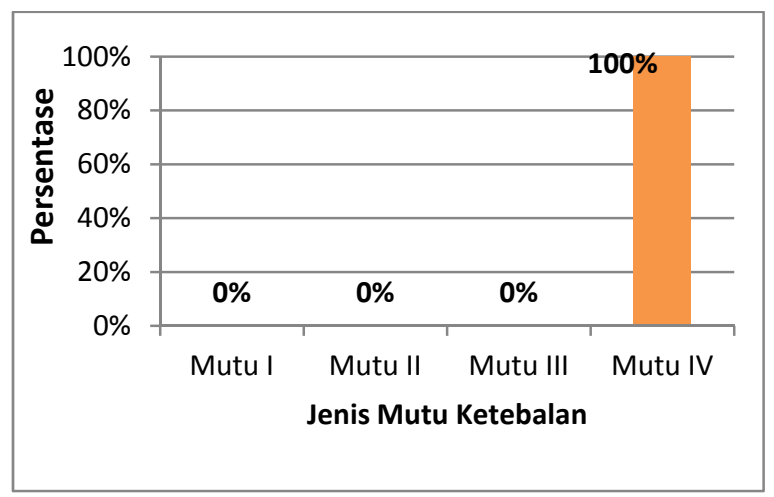

Gambar 1 Mutu ketebalan bokar petani berdasarkan SNI.

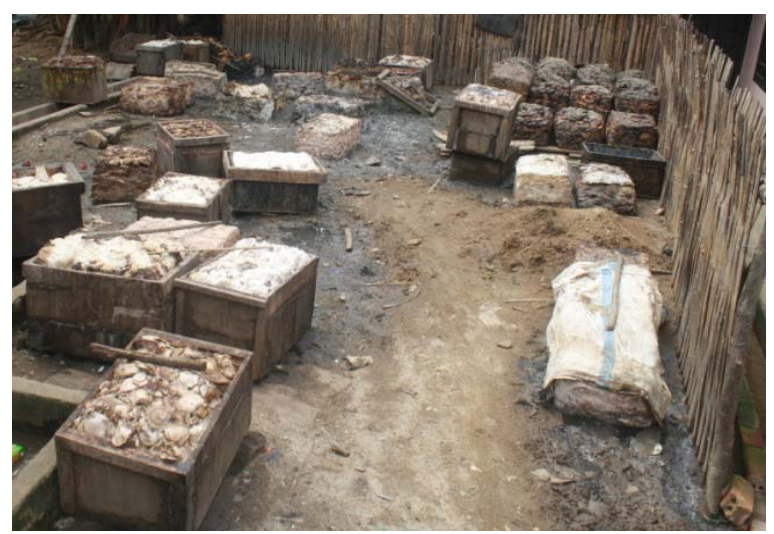

Gambar 2 Kondisi slab yang diproduksi petani.

Upaya mendapatkan bokar berupa slab yang memenuhi standar mutu I sampai mutu III dapat dilakukan dengan berbagai cara antara lain membuat slab hanya menggunakan lateks tanpa dicampur dengan lump mangkok. Apabila menggunakan lump mangkok yang cukup tebal maka dapat diproses lebih lanjut dengan menggiling slab tersebut menjadi slab tipis yang ketebalannya akan menjadi sekitar $5-10 \mathrm{~cm}$. Rendahnya mutu bokar yang dihasilkan petani di areal operasi tambang ini diduga karena minimnya pengetahuan dan adopsi teknologi pengolahan karet alam petani (Widyasari \& Rinojati, 2014) akibat dari akses informasi yang terbatas.

\subsection{Kebersihan}

Parameter yang menjadi indikator dalam penentuan mutu bokar berupa kebersihan terlihat pada Tabel 1. Bokar yang memenuhi standar SNI harus tidak mengandung kotoran/kontaminan. Hasil survei dan analisis yang dilakukan, diketahui bahwa bokar petani di areal operasional tambang migas di Kabupaten Musi Banyuasin semuanya mengandung kontaminan atau kotoran (Gambar 3).

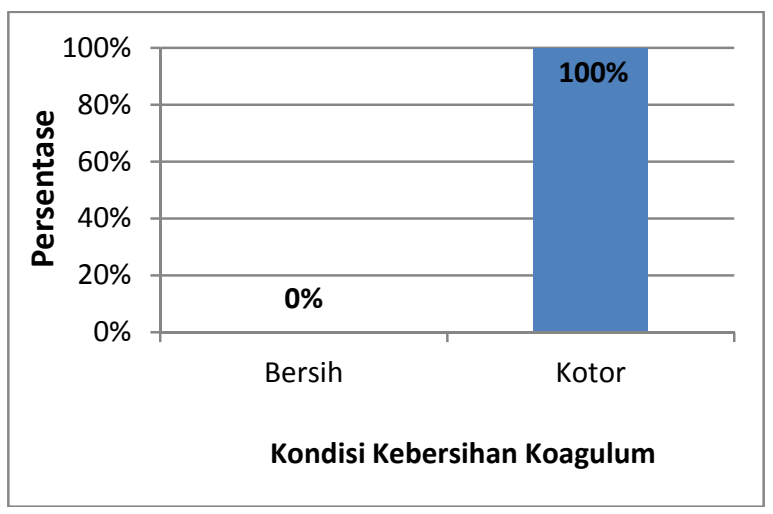

Gambar 3 Kondisi kebersihan bokar petani.

Kondisi bokar petani yang kotor ini lebih disebabkan oleh pola pikir dan perilaku petani itu sendiri. Perilaku umum yang dilakukan petani tersebut adalah menambahkan kulit kayu pohon karet sisa dari penyadapan atau biasa disebut tatal. Oleh karena itu, kontaminan atau kotoran yang paling umum ditemukan di bokar petani adalah tatal. Perilaku ini tumbuh karena petani berusaha menambah bobot slab yang dihasilkan dengan harapan mendapatkan penghasilan yang lebih banyak. Praktek ini dapat terjadi karena belum adanya perbedaan harga antara bokar bersih dan kotor dalam pemasaran atau jual-beli bokar. Nancy dkk. (2012) menyatakan bahwa belum adanya perbedaan harga yang signifikan antara bokar bersih dan kotor, karena volume bokar yang tidak ekonomis, mengakibatkan beberapa petani enggan memproduksi bokar bersih sesuai SNI.

Pemberlakuan perbedaan harga, akan menempatkan petani yang sudah menerapkan teknik pengolahan bokar yang bebas kontaminan mendapatkan penghasilan yang lebih baik. Hasil penelitian yang dilakukan Sannia dkk. (2013) menyatakan bahwa petani yang melakukan peningkatan kualitas bokar yang dihasilkan dengan tidak menambahkan kontaminan dan menggunakan bahan penggumpal asam semut, memberikan keuntungan tambahan pendapatan. Tambahan pendapatan ini berupa harga yang diterima lebih baik dibandingkan petani yang membuat bokar kotor.

\subsection{Jenis Koagulan}

Bahan penggumpal (koagulan) menjadi salah satu faktor penting yang menentukan mutu karet alam yang dihasilkan. Selain itu, penggunaan koagulan juga akan mempengaruhi tahapan proses (procces line) pengolahan karet dari bahan mentah (bokar) sampai menjadi karet ekspor dalam hal ini karet remah (crumb rubber). Karet remah Indonesia di dunia internasional dikenal dengan nama Standard Indonesian Rubber (SIR). Koagulan yang menghasilkan 
karet bermutu baik mempunyai keuntungan lain yaitu tidak memerlukan rantai/tahapan proses yang panjang terutama dalam proses penggilingan dan pembersihan. Oleh karena itu, penggunaan koagulan ajuran harus dilakukan untuk menghasilkan karet bermutu baik dan akhirnya mampu bersaing di pasar internasional.

Beberapa jenis koagulan yang dianjurkan penggunaannya karena menghasilkan karet bermutu baik adalah asam semut (Suwardin, 1990), asap cair (Solichin dkk., 2007) dan formula asap cair (Vachlepi \& Solichin, 2008). Penggunaan koagulan yang menghasilkan karet bermutu baik tercantum dalam persyaratan mutu SNI 06-2047-2002.

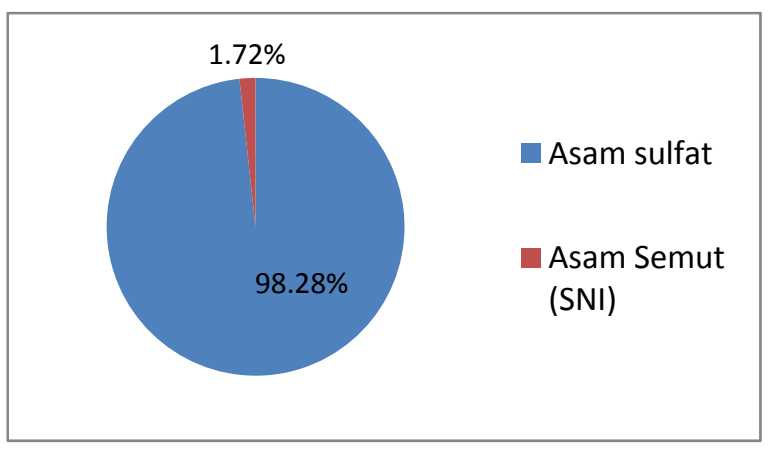

Gambar 4 Jenis koagulan yang digunakan oleh petani.

Berdasarkan SNI bokar (Tabel 1), koagulan yang boleh digunakan adalah asam semut dan bahan lain yang tidak merusak mutu karet. Terlihat pada Gambar 4 bahwa hanya 1,72 $\%$ bokar petani yang memenuhi standar mutu SNI. Bokar tersebut digumpalkan dengan asam semut atau asam format. Bokar sisanya sekitar 98,28 \% tidak memenuhi standar mutu karena menggunakan asam sulfat atau lebih dikenal cuka para sebagai koagulan. Asam sulfat merupakan oksidator kuat yang dapat memberikan dampak negatif pada nilai indeks ketahanan plastisitas (plasticity retention index/PRI) karet alam dan bersifat korosif. Vachlepi dkk. (2008) menyatakan bahwa nilai PRI yang tinggi menunjukkan bahwa karet tahan terhadap oksidasi khususnya suhu tinggi, sebaliknya karet dengan PRI rendah akan peka terhadap oksidasi dan suhu tinggi sehingga menjadi lunak.

Tingginya penggunaan asam sulfat oleh petani disebabkan bahan penggumpal ini termasuk yang paling mudah didapat di pasaran. Sebaliknya, bahan penggumpal yang direkomendasikan seperti asam semut dan asap cair jarang karena sulit diperoleh petani di pasaran (Syarifa dkk., 2013). Hasil penelitian Wiyanto dan Kusnadi (2013) menyatakan bahwa penyebab rendahnya mutu bokar yang dihasilkan perkebunan rakyat adalah penggunaan bahan penggumpal selain asam semut yang menyebabkan tingginya kadar abu dan rendahnya plastisitas awal.

\subsection{Tempat Penggumpalan}

Hasil survei yang dilakukan menemukan bahwa tempat atau wadah untuk penggumpalan yang digunakan petani di daerah tersebut cukup beragam, mulai dari bak plastik, kotak kayu sampai lubang tanah (Gambar 5). Tempat penggumpalan yang paling banyak digunakan adalah kotak kayu, sekitar 51,72 \%. Kotak kayu dipilih karena bahan bakunya mudah didapat di tingkat desa. Pembuatan bak penggumpal tidak memerlukan jenis kayu kelas kuat karenanya semua jenis kayu dapat digunakan. Alasan inilah yang membuat sebagian petani banyak memilih dan menggunakan kotak kayu untuk menggumpalkan dan mencetak bokar yang dihasilkan.

Tempat penggumpal kedua yang paling banyak digunakan adalah bak plastik, sebesar $39,66 \%$ dari 58 petani yang disurvei. Penggunaan bak plastik sebagai tempat penggumpalan sudah banyak diaplikasikan petani di daerah tersebut karena ketersediaannya yang mudah diperoleh. Petani tinggal membeli bak penggumpal di toko pertanian tanpa perlu bersusah payah membuat seperti kotak kayu. Kedua jenis bak penggumpal ini akan menghasilkan bokar yang bersih dengan syarat tidak dikotori secara sengaja oleh petani dan sebelum digunakan bak penggumpal tersebut harus dibersihkan terlebih dahulu.

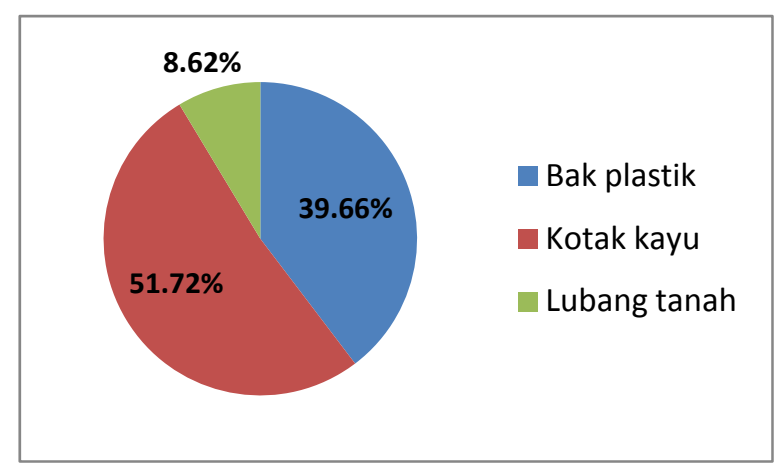

Gambar 5 Tempat atau wadah penggumpal yang digunakan petani untuk pembuatan bokar.

Petani karet di sekitar areal operasional tambang migas, selain menggunakan kotak kayu dan bak plastik, memanfaatkan lubang tanah sebagai tempat penggumpalan (Gambar 6). Penggunaan lubang tanah, sebenarnya tidak direkomendasikan sebagai tempat penggumpalan. Tanah yang menjadi tempat penggumpalan dapat menempel pada bokar sehingga menjadi kontaminan. Bokar yang mengandung kontaminan tidak memenuhi 
persyaratan mutu sesuai SNI 06-2047-2002 karena salah satu persyaratan mutunya tidak terdapat kotoran didalamnya. Kontaminan di dalam bokar sangat memengaruhi kadar kotoran produk karet remah. Kadar kotoran karet remah SIR 20 yang umumnya diproduksi dari bokar petani maksimal sebesar 0,16 \% (Badan Standardisasi Nasional, 2011). Tanpa pengolahan yang baik, karet remah yang dihasilkan dari bokar tersebut tidak memenuhi persyaratan mutu ekspor.

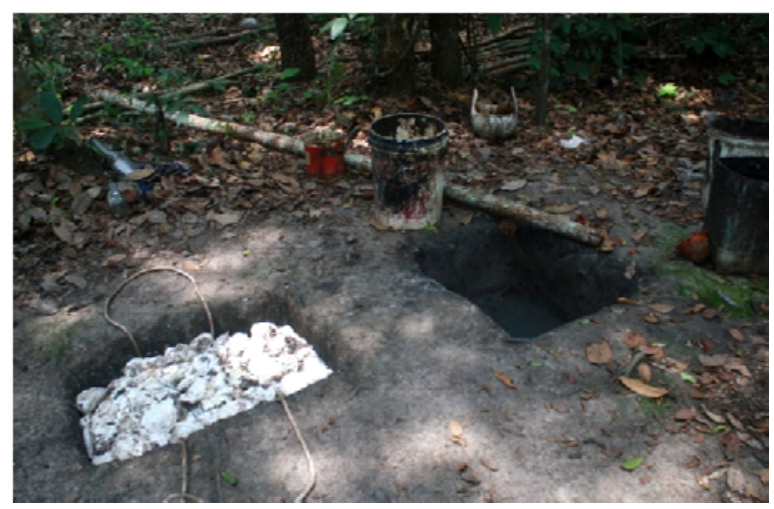

Gambar 6 Penggumpalan slab menggunakan lubang tanah.

Permendag No. 53 Tahun 2009 menjelaskan tanah merupakan salah satu jenis kontaminan yang termasuk dalam kategori berat. Penghilangan kontaminan tanah yang masuk dalam bokar memerlukan proses yang panjang sehingga membuat biaya produksi menjadi mahal dan kurang efisien. Oleh karena itu, penggunaan lubang tanah sebagai tempat penggumpalan harus dihindari.

\subsection{Kondisi Penyimpanan}

Hasil survei terhadap kondisi penyimpanan bokar yang dilakukan petani di areal operasional tambang disajikan pada Gambar 7. Berdasarkan hasil survei diketahui bahwa lebih dari 50\% petani di sekitar areal operasional tambang menyimpanan bokarnya dengan cara direndam dalam air. Tingginya jumlah petani yang merendam bokarnya diduga karena petani tersebut belum mendapatkan informasi mengenai pengaruh negatif perendaman bokar terhadap mutu. Intapun dkk. (2009) menyatakan bahwa kondisi lingkungan berpengaruh terhadap mekanisme biokimia dan pertumbuhan mikrobiologi selama penyimpanan.

Bokar yang direndam dalam air akan menjadi media pertumbuhan mikroorganisme. Protein yang terdapat di permukaan partikel karet alam akan dihidrolisis baik oleh mikroorganisme maupun secara enzimatis (Santosa, 1991) menjadi $\mathrm{H}_{2} \mathrm{~S}$ yang menyebabkan bau busuk. Hidrolisis protein akan menimbulkan bau busuk dan menyebabkan partikel karet alam akan mudah teroksidasi. Hal ini ditandai dengan terputusnya rantai polimer karet alam menjadi lebih pendek. Mengakibatkan nilai plastisitas karet menjadi rendah. Karet alam dengan nilai plastisitas yang rendah tidak memenuhi standar mutu ekspor sesuai dengan SNI 1903:2011 tentang Karet Spesifik Teknis yang merevisi Standard Indonesian Rubber (SIR). Perendaman umumnya dilakukan sampai waktu penggumpalan (Feramune \& Budiman, 2007) bahkan ada yang sampai waktu penjualan bokar. Penyimpanan bokar dengan cara direndam tidak diperkenankan karena dapat menurunkan mutu karet yang dihasilkan.

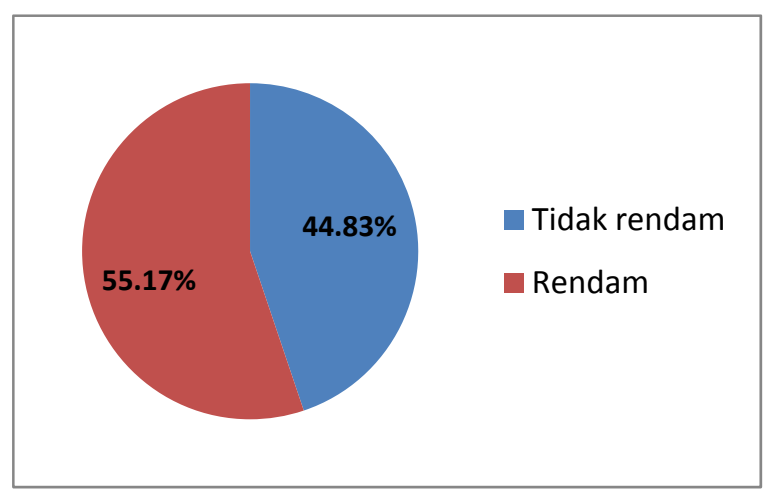

Gambar 7 Persentase cara penyimpanan bokar yang dilakukan petani.

Terlihat pada Gambar 7 persentase petani yang tidak merendam bokar sekitar 44,83\%. Angka ini menunjukkan bahwa beberapa petani sudah menerapkan teknik pengolahan bokar yang baik dan tepat. Bokar harus disimpan ditempat yang kering dan terhindar dari sinar matahari langsung (tertutup) agar mutunya tetap baik. Beberapa kelompok petani yang menerapkan sistem lelang sebagian sudah memiliki gudang untuk penyimpanan bokar.

\section{KESIMPULAN}

Mutu bokar berupa slab yang dihasilkan petani karet di sekitar areal operasional tambang migas Kabupaten Musi Banyuasin, Sumatera Selatan secara umum belum memenuhi standar baku yang dipersyaratkan SNI 06-2047-2002. Ketebalan slab yang dihasilkan $100 \%$ termasuk dalam mutu IV dan penggunaan bahan penggumpal yang sesuai dengan persyaratan SNI hanya $1,72 \%$. Seluruh slab yang dihasilkan petani $100 \%$ kotor. Tempat penggumpal yang digunakan beragam, yaitu bak plastik, kotak kayu dan lubang tanah.

Petani karet di sekitar areal operasional tambang disarankan mendapatkan bimbingan teknis mengenai pengolahan bokar yang baik 
dan sesuai dengan standar mutu SNI. Pelaksanaan kegiatan ini dapat didanai melalui kegiatan Tanggung Jawab Sosial Lingkungan (TJSL) atau Corporate Social Responsibility (CSR) dari perusahan migas yang secara konsisten peduli dengan masyakarat yang berada di areal kerjanya.

\section{UCAPAN TERIMA KASIH}

Pada kesempatan ini penulis mengucapkan terima kasih kepada Balai Penelitian Sembawa yang sudah mengizinkan pelaksanaan kegiatan penelitian ini.

\section{DAFTAR PUSTAKA}

Badan Pusat Statistik. (2013). Statistik Karet Indonesia 2013. Jakarta: Badan Pusat Statistik.

Badan Standardisasi Nasional. (2002). Standar Nasional Indonesia SNI 06-2047-2002: Bahan Olah Karet. Jakarta: Badan Standardisasi Nasional.

Badan Standardisasi Nasional. (2011). Standar Nasional Indonesia SNI 1903-2011: Karet Spesifikasi Teknis. Jakarta: Badan Standardisasi Nasional.

Feramune, M. R. dan Budiman, A. F. S. (2007). $A$ value chain assesment of the rubber industry in Indonesia. Jakarta: USAID.

Handayani, H. (2014). Pengaruh berbagai jenis penggumpal padat terhadap mutu koagulum dan vulkanisat karet alam. Jurnal Penelitian Karet, 32, 1, 74-80.

Intapun, J., Sainte-Beuve, J., Bonfils, F., Tanrattanakul, V., Dubreucq, E., \& Vaysse, L. (2009). Characterisation of natural rubber cup coagula maturation condition and consequences on dry rubber properties. Journal of Rubber Research, 12, 4, 171-184.

Kementerian Perdagangan. (2009). Peraturan Menteri Perdagangan No. 53/MDAG/PER/10/2009 tentang pengawasan mutu bahan olah komoditi ekspor Standard Indonesian Rubber yang diperdagangkan. Jakarta: Kementerian Perdagangan.

Kementerian Pertanian. (2008). Peraturan Menteri Pertanian No. 38/Permentan/OT.140/8/2008 tentang pedoman pengolahan dan pemasaran bahan olah karet. Jakarta: Kementerian Pertanian.
Nancy, C., Syarifa, L. F., Agustina, D. S., Alamsyah, A., \& Nugraha, I.S. (2012). Pengembangan pemasaran bahan olah karet. Palembang: Dinas Perkebunan Provinsi Sumatera Selatan dan Balai Penelitian Sembawa.

Sannia, B., Ismono, R. H., \& Viantimala, B. (2013). Hubungan kualitas karet rakyat dengan tambahan pendapatan petani di desa program dan non-program. Jurnal IImu-IImu Agribisnis, 1, 1, 36-43.

Santosa, A. M. (1991). Pengaruh kondisi penggumpalan lateks terhadap sifat-sifat karet alam. Buletin Penelitian Karet, 7, 2, 88-93.

Setiawan, H. (2012). Technology innovation roadmap to industrial development or rubber-raw material in South Sumatera (Ergonomics SHIP approach and approriate technology point of view). Procedia Economics and Finance, 4, 255-263.

Solichin, M., Anwar, A., \& Tedjaputra, N. (2007). Penggunaan asap cair Deorub dalam pengolahan RSS. Jurnal Penelitian Karet, 25, 1, 83-94.

Solichin, M., Suwardin, D., \& Vachlepi, A. (2012). Pengolahan Karet. Pangkalan Balai: Balai Penelitian Sembawa.

Suwardin, D., \& Nancy, C. (1994). Masalah dan upaya peningkatan mutu bahan olah karet. Pangkalan Balai: Balai Penelitian Sembawa.

Suwardin, D. (1991). Kajian perkembangan mutu bahan olah karet rakyat. Lateks, 6, 2, 6468.

Suwardin, D. (1990). Pengaruh bentuk penampung lateks dan penambahan asam semut serta lama pemeraman terhadap mutu koagulum. Buletin Perkebunan Rakyat, 6, 2, 46-52.

Syarifa, L. F., Agustina, D. S., Nancy, C., \& Supriadi, M. (2012). Evaluasi tingkat adopsi klon unggul di tingkat petani karet di Provinsi Sumatera Selatan. Jurnal Penelitian Karet, 30, 1, 12-22.

Syarifa, L. F., Agustina, D. S., \& Nancy, C. (2013). Evaluasi pengolahan dan mutu bahan olah karet rakyat di tingkat petani karet di Sumatera Selatan. Jurnal Penelitian Karet, 31, 2, 139-148.

Vachlepi, A \& Solichin, M. (2008). Aplikasi formula asap cair Deorub $\mathrm{K}$ sebagai penggumpal lateks. Warta Perkaretan, $27,2,80-87$. 
Vachlepi, A., Solichin, M., \& Anwar, A. (2008). Pengaruh berbagai koagulan lateks terhadap kondisi penggumpalan, spesifikasi teknis, karakteristik vulkanisasi dan sifat fisik vulkanisat. Buletin Penelitian Universitas Djuanda, $3,2,123-132$.

Widyasari, T., \& Rinojati, N. D. (2014). Studi pendahuluan terhadap karakteristik usaha tani karet di daerah lingkar tambang studi kasus di Kabupaten Berau, Povinsi Kalimantan Timur. Warta Perkaretan, 33, 1, 47-56.
Wiyanto \& Kusnadi, N. (2013). Faktor-faktor yang mempengaruhi kualitas karet perkebunan rakyat. Jurnal Agribisnis Indonesia, 1, 1, 39-58. 